\title{
Arahan Penataan Bangunan dan Lingkungan Pada Kawasan Keraton Pakunegara Tayan Kabupaten Sanggau Kalimantan Barat
}

\author{
Buildings and Environtment Urban Guidelines of Pakunegara Tayan \\ Palace Sanggau Regency West Kalimantan
}

Dian Perwita Sari ${ }^{1}$ dan M. Ridha Alhamdani²

Diterima: 22 Januari 2020

Disetujui: 31 Agustus 2020

\begin{abstract}
Abstrak: Kawasan Keraton Pakunegara Tayan, Kabupaten Sanggau Kalimantan Barat saat ini memerlukan adanya penataan dalam wujud arahan dan guideline penataan bangunan dan lingkungan kawasan agar dapat tertata dengan baik. Perkembangan kota yang cepat dan tidak terkendali, daya dukung lingkungan yang menurun, perkembangan bangunan yang sudah tidak mengikuti aturan yang berlaku menjadi faktor utama perlunya penataan kawasan. Dalam penelitian ini menggunakan metode penelitian deskriptif kualitatif. Pendekatan deskriptif bertujuan menggambarkan keadaan saat ini dengan tujuan mengidentifikasi kondisi eksisting kawasan Keraton Pakunegara Tayan. Selain itu, pendekatan deskriptif kualitatif digunakan untuk memeriksa sebab akibat melalui identifikasi dari gejala dari permasalahan yang ada kemudian dari hasil analisa dibuatlah skema konsep penataan kawasan. Hasil dari penelitian ini menghasilkan dua konsep penataan Kawasan Keraton Pakunegara Tayan yaitu pembangunan yang adaptif (adaptive development) dan pembangunan yang terpadu (integrated development), di mana masing-masing konsep tersebut dikembangkan dan dielaborasikan dengan elemen urban desain sehingga dapat memberikan arahan perwujudan fisik Kawasan Perkotaan, yang mengacu pada Rencana Tata Ruang (RTR) serta kaidah/ norma-norma sosial kultural setempat, agar tercipta suatu lingkungan yang terencana, tertib, aman, nyaman, serasi, produktif dan berkelanjutan di kawasan Keraton Pakunegara Tayan.
\end{abstract}

Kata kunci: penataan, adaptif development, integrated development, berkelanjutan

\begin{abstract}
The area of the Palace of Pakunegara Tayan, Sanggau Regency, West Kalimantan, currently requires arrangement in the form of directions and guidelines of buildings and environment for the region so it could be ordering. The uncontrolled and rapid development reduces the carrying capacity of the environment, the building's growth does not follow the applicable rules are the main factors for regional management. This study used descriptive qualitative research methods. The descriptive qualitative method aims to describe the current situation to identify the existing conditions of the Keraton Pakunegara Tayan area. Besides, this approach used to examine cause and effect through the identification of symptoms from existing problems and from the analysis, the regional arrangement concept scheme made. The results of this study obtain two concepts of structuring the Pakunegara Tayan Palace Area, they are adaptive development and integrated development, where each concept developed and elaborated with urban design elements so can provide direction for the physical manifestation of the Urban Area, which refers to the Spatial Plan (RTR) as well as local socio-cultural norms/norms, to create environment well planned, orderly, safe, comfortable, harmonious, productive and sustainable in surroundings of the Keraton Pakunegara Tayan area.
\end{abstract}

Keywords: guideline, adaptive development, integrated development, sustainable

\footnotetext{
${ }^{1}$ Jurusan Teknik Arsitektur dan Perencanaan Politeknik Negeri Pontianak

${ }^{2}$ Jurusan Teknik Arsitektur, Fakultas Teknik, Universitas Tanjungpura
} 


\section{PENDAHULUAN}

Perkembangan perkotaan cenderung mengarah terbentuknya kawasan perkotaan yang semakin membesar dan terintegrasi. Kondisi tersebut terlihat dari semakin luasnya daerah yang menunjukkan ciri fisik perkotaan di kawasan suburban yang telah menyatu dengan kota intinya (Yahya, 2015). Fenomena ini mengakibatkan perkembangan kota dan kawasan menjadi tidak terkontrol akibat kurangnya arahan penataan bangunan dan lingkungan. Perkembangan wilayah kota-kota menengah maupun kota-kota kecil di sekitarnya sebagai akibat dari proses modernisasi dan industrialisasi kota besar (inti), dimana pada akhirnya mengakibatkan perkembangan kota-kota tersebut terkesan menyatu (Nurcholis, 2008 dalam Yahya, 2015).

Perkembangan kota yang tidak direncanakan dengan baik akan mengakibatkan penataan bangunan dan lingkungan menjadi tidak terkendali. Arahan penataan bangunan dan lingkungan harus sesuai dengan tata ruang yang ada. Arahan ini bertujuan mengatur perkembagan kota terutama kawasan yang mampu beradaptasi dengan proses transformasi sosio-ekonomi kota. Adanya arahan penataan untuk meningkatkan aspek-aspek kualitas ruang kota secara visual maupun fungsional. Sebagai kelanjutan dari rencana kota yang telah ada, maka arahan atau rencana tata bangunan dan lingkungan lebih memberikan arahan dan aturan pembangunan secara 3 dimensi, seperti Koefisien Dasar Bangunan (KDB), Koefisien Lantai Bangunan (KLB), Garis Sempadan Bangunan (GSB), ketinggian bangunan dan Koefisien Dasar Hijau (KDH). Bangunan sebagai elemen fisik utama akan banyak dikaji, kemudian elemen-elemen pembentuk kawasan seperti jalan dan ruang-ruang terbuka (street and square). Arahan penataan bangunan dan lingkungan dimaksudkan untuk melengkapi peraturan daerah, meningkatkan kualitas bangunan gedung dan lingkungan yang memiliki kesatuan karakter serta menjamin implementasi pembangunan dan menjamin terpeliharanya hasil pembangunan dengan mendayaupayakan peran masyarakat (Dwijaya, 2016)

Banyak sekali upaya penelitian-penelitian kota dalam menata lingkungannya sesuai dengan konsep pendekatan yang telah dikaji dengan dalam. Penelitian yang dilakukan Yunianto, dkk, (2016)misalnya berfokus pada analisis penyediaan dan desain RTH yang mempertimbangkan pola aktivitas dan fungsi RTH untuk terciptanya RTH publik berbasis green design (Asirin \& Zanith, 2017). Adapun penelitian lainnya pada tata lingkungan dilakukan oleh Drianda, dkk, (2015) dalam penelitian Drianda, dkk, (2015) berfokus pada tata lingkungan yang ramah dan aman untuk anak, penelitian ini mengambil studi kasus Kota Tokyo Jepang, menurut Drianda, dkk, (2015) Jepang telah melakukan penataan lingkungan kota yang aman untuk anak, namun penelitian ini belum menggali kondisi dan dan potensi yang ada di Indonesia. Sementara itu, Rohe (2009) dalam tulisannya medefinisikan penataan lingkungan adalah kegiatan mendesain lingkungan baru atau merevitalisasi kembali lingkungan yang lama. Sedangkan, Checkoway (1985) menyatakan bahwa penataan lingkungan adalah suatu proses masyarakat mengembangkan rencana, program, atau layanan sosial pada tingkat lingkungan ketetanggan (neighborhood). Checkoway (1985) menambahkan lagi bahwa penataan lingkungan tidak hanya pengembangan fisik tetapi juga pengembangan layanan sosial pada tingkat lingkungan (Checkoway dalam Asirin \& Zanith, 2017). Tallo, A.J. \& Paramita (2015) berpendapat hal yang sama bahwa warga dapat berpartisipasi dalam proses perencanaan pembangunan tanpa campur tangan pemerintah.

Kawasan Keraton Pakunegara Tayan memiliki gabungan kriteria suatu kawasan yang memerlukan penyusunan arahan penataan bangunan dan lingkungan. Hal ini karena kawasan ini merupakan termasuk bangunan cagar budaya (konservasi) yang perlu dilestarikan serta memiliki kondisi alam sungai yang juga harus dijaga. Di sisi lain merupakan area terbangun yang cenderung cepat dan rawan terhadap bencana alam khususnya banjir yang mengancam permukiman dan Kawasan Keraton Pakunegara Tayan itu sendiri. Letak Kawasan Keraton Tayan tepat berada di jantung kota Tayan, tepat di area 
tepi sungai dan menghadap sungai Kapuas. Potensi wisata Kawasan Keraton Pakunegara Tayan yang sampai saat ini masih belum dikembangkan secara optimal baik dari kelayakannya sebagai kawasan wisata budaya (Heritage), atraksi/kegiatan wisata dan infrastruktur dari kawasan wisata tersebut. Dari permasalahan-permasalahan di atas maka perlu dilakukannya penataan kembali kawasan ini dari sisi tata bangunan dan lingkungan sehingga menjadikan kawasan Keraton Pakunegara Tayan menjadi kawasan yang produktif dengan tetap mempertahankan nilai historisnya.

Keraton Pakunegara Tayan merupakan kawasan bersejarah yang terdapat di Kota Tayan dan menjadi core daya tarik wisata kota Tayan Kabupaten Sanggau Kalimantan Barat. Masuk ke dalam bangunan cagar budaya yang tertuang dalam Undang-undang cagar budaya (UU Cagar Budaya, 2010). Keraton Pakunegara Tayan adalah salah satu bentuk peninggalan sejarah khususnya berkaitan dengan perkembangan kebudayaan keratonkeraton Melayu di Kalimantan Barat. Keraton Tayan didirikan oleh Gusti Lekar (1683-1718) adalah anak kedua dari Panebahan Dikri (Raja Matan) Putera Mahkota Duli Maulana Sultan Muhammad Syarifudin. Status keraton Pakunegara dijadikan monument peninggalan sejarah yang dilindungi (Monumen Ordonansi No. 238 tahun 1931) dari Pemerintahan Daerah Tk. I Kalimantan Barat. Keraton Pakunegara Tayan merupakan komplek istana yang terdiri dari Istana sebagai pusat pemerintahan, masjid Jami' dan makam kerajaan. Masjid Jami' konon menurut penduduk sekitar masjid ini selalu berpindahpindah apabila pusat kerajaan oleh para Raja Tayan dipindahkan. Keraton ini merupakan lokasi keraton yang terakhir dari Kerajaan Tayan setelah berpindah dari bagian hulu dari Sungai Tayan. Lokasi di tepi Sungai Kapuas, berjarak 50 meter, orientasi menghadap ke Sungai Kapuas, ke arah selatan. Saat ini bangunan keraton tidak digunakan untuk rumah tinggal, tetapi bangunan kosong dan hanya digunakan untuk even-even tertentu (Sarjiyanto \& Inagurasi, 2015)

Keraton Pakunegara Tayan berada di Kecamatan Tayan Hilir tergolong strategis karena terletak pada jalur Jalan Trans Kalimantan dan berada pada jalur sungai Kapuas. Jarak tempuh melalui jalan yang ada pada saat ini dari Kota Tayan ke Ibu Kota Kabupaten Sanggau adalah $\pm 100 \mathrm{~km}$, sedangkan jarak tempuh ke Pontianak-Ibu Kota Propinsi Kalimantan Barat adalah $\pm 110 \mathrm{~km}$ dengan kondisi jalan 95\% telah beraspal. Morfologi kota Tayan dimaknai secara filosofi melahirkan persepsi ruang kota dengan pola "kepala-badanekor", terutama secara tradisi Melayu, sungai sering diposisikan secara horizontal. Sehingga unuk menandai suatu lokasi di tepian sungai seringkali digunakan istilah kepala (hulu) dan ekor sebagai arah mengalirnya air sungai. Hal ini bersifat simbiosis dalam berinteraksi dengan alam serta berusaha mengisi setiap ruang yang ada secara lebih fleksibel/luwes. Seiring perkembangan kota Tayan peningkatan perekonomian masyarakat sedikit banyak mempengaruhi fasad bangunan arsitektur lama (rumah panggung) yang semula berorientasi ke sungai menjadi bangunan dengan arsiektur yang bergaya modern. Secara historis eksistensi terbentuknya komunitas masyarakat tepian sungai dapat dibedakan menjadi dua kelompok. Pertama, masyarakat dengan tradisi menetap dan berkembang pada lokasi tepian sungai dengan basis budaya perairan. Kedua, kelompok masyarakat yang menghuni kawasan tepian air akibat proses urbanisasi dengan dasar pertimbangan budaya huni pada keterbatasan lahan (masyarakat 'marginal').

Saat ini seiring meningkatnya jumlah warga dan kegiatan yang berlangsung di sekitar kawasan Keraton Pakunegara Tayan, menimbulkan banyak permasalahan baik dari segi lingkungan, sosial, maupun ekonomi. Permasalahan tersebut antara lain: 1) alih fungsi sempadan sungai menjadi permukiman padat yang cenderung menjadi kumuh dan tidak sehat, 2) sampah dan limbah domestik yang dibuang ke sungai tanpa pengolahan, 3) degradasi ruang terbuka hijau akibat pembangunan yang kurang memperhatikan lingkungan, 4) sistem parkir yang tidak teratur sehingga mngakibatkan banyak turis yang datang memarkirkan kendaraannya sembarangan dan masih banyak permasalahanpermasalahan lainnya. 


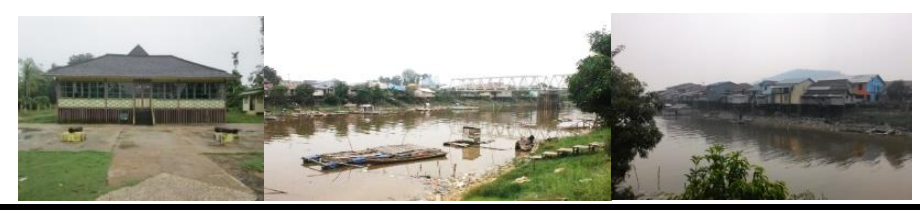

\section{Gambar 1. (kiri) Keraton Pakunegara Tayan, (tengah) sumber air baku yang tercemar sampah, (kanan) permukiman sungai}

Urgensi penataan kawasan Keraton Pakunegara Tayan adalah rangkaian upaya untuk meningkatkan kawasan yang memiliki potensi dan nilai strategis dan mengembalikan vitalitas kawasan yang telah atau mengalami penurunan, agar kawasan Keraton Pakunegara Tayan bisa mendapatkan nilai tambah yang optimal terhadap produktifitas ekonomi, sosial dan budaya kawasan perkotaan. Penataan kawasan Keraton Pakunegara Tayan dilakukan melalui pengembangan kawasan-kawasan tertentu yang layak untuk ditata baik dari segi setting kawasan sehingga kawasan Keraton Pakunegara Tayan dapat terintegrasi dalam satu kesatuan yang utuh dengan sistem kota, dengan meningkatkan prasarana sarana sehingga terbentuk kenyamanan lingkungan kota, yang pada akhirnya berdampak pada peningkatan kualitas hidup masyarakat yang tinggal di sekitar Keraton Pakunegara Tayan. Gusti Yusri (Raja Keraton Pakunegara Tayan) menambahkan tata ruang di Tayan masih belum tertata dengan baik, di Tayan terdapat perikanan air tawar yang sangat potensial, namun karena penataan ruang wilayah tidak diperhatikan sehingga lambat laut potensi tersebut mulai terkikis (Maulid, 2018).

Tujuan penelitian ini adalah untuk menetapkan fungsi dan peranan kawasan Keraton Pakunegara Tayan dalam konteks Kawasan Perkotaan, mengarahkan keserasian bangunan (arsitektural) dan ruang antar bangunan (spasial) yang terdapat di kawasan perencanaan untuk mendukung identitas dan citra kota, memberikan arahan penataan di kawasan Keraton Pakunegara Tayan dan ruang terbukanya sehingga tercipta tata lingkungan yang proporsional, serta mengintegrasikan pembangunan sarana prasarana dalam kawasan perencanaan dalam wujud tiga dimensi yang sejalan dengan rencana penataan kota dan dapat dioperasionalkan.

\section{Intensitas Pemanfaatan Ruang dan Tata Bangunan}

Menurut Permen PU Nomor 06/PRT/M/2007 tentang Rencana Tata Bangunan dan Lingkungan, intensitas pemanfaatan ruang adalah tingkat alokasi dan distribusi luas lantai maksimum bangunan terhadap lahan/tapak peruntu-kannya (Kementrian Pekerjaan Umum, 2007). Intensitas pemanfaatan ruang atau penggunaan lahan ini merupakan variabel untuk melihat elemen yang mempengaruhi morfologi kota yaitu bentuk dan massa bangunan (Yahya, 2015). Tata bangunan menurut (Yahya, 2015) adalah produk dari penyelenggaraan bangunan gedung beserta ling-kungannya sebagai wujud pemanfaatan ruang, meliputi berbagai aspek termasuk pembentuk cita/karakter fisik lingkungan, besaran, dan konfigurasi dari elemen-elemen: blok, kaveling /petak lahan, bangunan serta ketinggian dan elevasi lantai bangunan, yang dapat mencip-takan dan mendefinisikan berbagai kualitas ruang kota yang akomodatif terhadap kera-gaman kegiatan yang ada, terutama yang berlangsung dalam ruang-ruang publik.

\section{Elemen Pembentuk Kawasan kota}

Shirvani (1985) dalam bukunya Urban Design Process, terdapat 8 elemen dalam membentuk suatu kawasan kota, yakni: Tata Guna Lahan (Land Use), Bentuk dan Kelompok Bangunan (Building and Mass Building), Ruang Terbuka (Open Space), Parkir dan Sirkulasi (Parking and Circulation), Tanda-tanda (Signages), Jalur Pejalan Kaki (Pedestrian Ways), Pendukung Kegiatan (Activity Support), dan Preservasi (Preservation). Tata guna lahan adalah 
rancangan dua dimensi denah lahan sebuah kota. Pada prinsipnya, pengertian tata guna lahan adalah pengaturan penggunaan lahan untuk menentukan pilihan yang terbaik dalam mengalokasikan fungsi tertentu, sehingga dapat memberikan gambaran keseluruhan bagaimana daerah-daerah pada suatu kawasan tersebut seharusnya berfungsi (Shirvani, 1985 dalam Nurjanah (2017)). Bentuk dan massa bangunan ditentukan oleh tinggi dan besarnya bangunan, KDB, KLB, sempadan, skala, material, warna, dan sebagainya supaya ruang yang terbentuk teratur dan memiliki skyline yang dinamis serta menghindari ruang-ruang yang tidak terpakai.

Open space selalu berhubungan dengan lansekap. Lansekap terdiri dari elemen keras dan elemen lunak. Open space biasanya berupa lapangan, jalan, sempadan, sungai, taman, makam, dan sebagainya. Dalam perencanaan ruang terbuka akan terkait dengan street furniture seperti tong sampah, lampu jalan, bangku taman, papan nama dan lain-lain. Shirvani menyebutkan sirkulasi kota meliputi prasarana jalan yang tersedia, bentuk struktur kota, fasilitas pelayanan umum, dan jumlah kendaraan bermotor yang semakin meningkat. Semakin meningkatnya transportasi maka area parkir sangat dibutuhkan terutama di pusatpusat kegiatan kota (CBD). Sedangkan penanda (Signages) menurut (Shirvani, 1985)adalah petunjuk arah jalan, rambu lalu lintas, media iklan, sclupture, dan berbagai bentuk penandaan lain. Keberadaan penandaan akan sangat mempengaruhi visualisasi kota, baik secara makro maupun mikro. Jalur Pejalan Kaki (Pedestrian Ways) harus dibantu dengan interaksinya pada elemen-elemen dasar desain tata kota dan harus berkaitan dengan lingkungan kota dan pola-pola aktivitas serta sesuai dengan rencana perubahan atau pembangunan fisik kota di masa mendatang.

Aktivitas pendukung yaitu semua fungsi bangunan dan kegiatan-kegiatan yang mendukung ruang publik kota. Bentuk, lokasi dan karakter suatu kawasan yang memiliki ciri khusus akan berpengaruh terhadap fungsi, penggunaan lahan dan kegiatan pendukungnya. Aktivitas pendukung tidak hanya menyediakan jalan pedestrian atau plasa, tetapi juga mempertimbangkan fungsi utama dan penggunaan elemen-elemen kota yang dapat menggerakkan aktivitas pendukung kegiatan sebagai salah satu elemen perancangan kota sangat berkaitan dengan pertumbuhan fungsi-fungsi kegiatan umum ruang kota (Shirvani, 1985 dalam Nurjanah (2017)). Shirvani mengemukakan preservasi dalam perancangan kota adalah perlindungan terhadap lingkungan tempat tinggal (permukiman) dan urban places (alun-alun, plasa, area perbelanjaan) yang ada dan mempunyai ciri khas seperti halnya perlindungan terhadap bangunan bersejarah.

\section{METODE}

Metode penelitian yang digunakan adalah metode penelitian deskriptif kualitatif. Pendekatan deskriptif kualitatif bertujuan menggambarkan keadaan yang sedang berlangsung saat ini yang bertujuan mengidentifikasi kondisi eksisting kawasan Keraton Pakunegara Tayan. Tujuan dari metode ini adalah untuk menggambarkan suatu keadaan yang ada pada saat penelitian dilakukan dan memeriksa sebab akibat melalui identifikasi dari gejala dari permasalahan yang ada. Melakukan pengamatan langsung, mengumpulkan data-data kemudian menghubungkannya dengan kajian teori yang digunakan. Metode pengumpulan data dengan cara observasi lapangan, dan studi literatur. Data ini berfungsi sebagai dasar dalam melakukan analisis terhadap masalah yang dibahas. Data yang dikumpulkan merupakan data primer dan data sekunder. Menurut (Moleong, 2017) dalam bukunya mengutip beberapa penulis adalah penelitian yang bermaksud memahami fenomena tentang apa yang dialami oleh subyek (perilaku, persepsi, motivasi, tindakan, dan lain-lain) secara holistik, dan dengan cara deskripsi dalam bentuk kata-kata dan bahasa, pada suatu konteks khusus yang alamiah dan dengan memanfaatkan berbagai metoda alamiah.

Deliniasi lokasi penelitian adalah seluas $\pm 17,36 \mathrm{Ha}$. Secara fisik batas administratif kawasan yang diteliti dibatasi oleh jalan-jalan utama kota dan kawasan permukiman penduduk. Adapun batas jalan utama ditetapkan sebagai deliniasi fisik pada kawasan karena 
adanya hubungan akses keluar masuk ke keraton Pakunegara Tayan dan permukiman pinggir Sungai Kapuas dengan jaringan jalan utama kota. Batasan fisik antara lain:

- Batas barat, Permukiman Penduduk sungai Kapuas, dan Pasar Kawat.

- Batas selatan, Sungai Kapuas dan Desa Pulau.

- Batas timur dan Batas utara, Jalan Gusti Djafar, Permukiman Penduduk, dan tempat usaha.

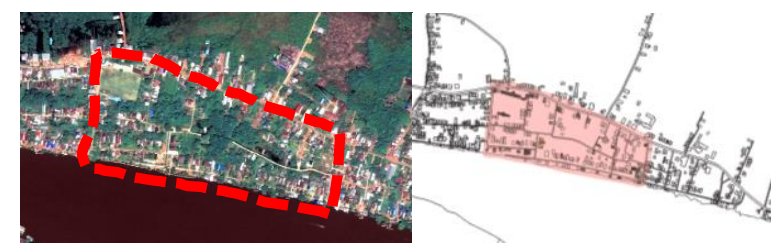

\section{Gambar 2. (kiri) Lokasi Penelitian, (kanan) Deliniasi kawasan penelitian}

Teknik pengumpulan data dilakukan dengan cara wawancara, studi literatur, observasi lapangan. Selain ketiga teknik pengumpulan data tersebut penelitian juga melibatkan partisipasi masyarakat dalam wujud Forum Discussion Group (FGD) tujuan FGD ini sebagai dasar bagi pendekatan "community driven planning" yang menjadikan masyarakat sebagai penentu sedangkan peran pemerintah adalah sebagai fasilitator. Data sekunder diperoleh dari berbagai sumber antara lain: hasil penelitian terkait dengan tema, review literature, data statistik, dokumen lainnya yang relevan (informasi dari media massa, arsip, foto, dan lain-lain) (Ardhiansyah, Widyastuti, \& Septiari, 2019)

Tabel 1. Data Primer dan Sekunder

\begin{tabular}{|c|c|c|}
\hline Data & Teknik Pengumpulan & Hasil \\
\hline Kondisi Eksisting & Observasi lapangan & - Mengetahui keadaan sebenarnya di kawasan \\
\hline Kawasan Keraton & & Keraton Pakunegara Tayan \\
\hline Pakunegara Tayan & & $\begin{array}{l}\text { - Mengetahui permasalahan di lapangan } \\
\text { - Foto-foto kondisi eksisiting }\end{array}$ \\
\hline Tata guna lahan & - Data citra satelit & - Peta figure ground \\
\hline & - Observasi lapangan & - Peta tata guna lahan \\
\hline $\begin{array}{l}\text { Intensitas Pemanfaatan } \\
\text { Lahan }\end{array}$ & Observasi lapangan & Peta pemanfaatan lahan \\
\hline $\begin{array}{l}\text { Sirkulasi dan jalur } \\
\text { penghubung }\end{array}$ & Observasi lapangan & Foto-foto kondisi eksisting \\
\hline Tata bangunan & Observasi lapangan & Foto-foto kondisi eksisting \\
\hline $\begin{array}{l}\text { Ruang terbuka dan tata } \\
\text { hijau }\end{array}$ & Observasi lapangan & Peta ruang terbuka dan tata hjau \\
\hline Kondisi bentang alam & Observasi lapangan & Foto-foto kondisi eksisting \\
\hline Sumber daya air & Observasi lapangan & Foto-foto kondisi eksisting \\
\hline Kawasan konservasi & Observasi lapangan & Foto-foto kondisi eksisting \\
\hline $\begin{array}{l}\text { Kondisi umum kota } \\
\text { Tayan }\end{array}$ & $\begin{array}{l}\text { BPS, RTRW Kab. } \\
\text { Sanggau }\end{array}$ & $\begin{array}{l}\text { Peta administrasi kota Tayan, kondisi umum Kota } \\
\text { Tayan, Topografi, kondisi iklim, sarana dan } \\
\text { prasarana, peta Rencana Tata Ruang Kota Tayan }\end{array}$ \\
\hline
\end{tabular}

Sumber: Hasil Olahan Data Lapangan, 2019

Variabel yang digunakan untuk melihat kawasan Keraton Pakunegara Tayan menggunakan 8 elemen pembentuk kawasan kota Shirvani, yakni: Tata Guna Lahan, Bentuk dan Kelompok Bangunan, Ruang Terbuka, Parkir dan Sirkulasi, Tanda-tanda, Jalur Pejalan Kaki, Pendukung Kegiatan, dan Preservasi. 
Tabel 2. Variabel Penelitian

\begin{tabular}{|c|c|c|}
\hline Konsep & Variabel & Indikator \\
\hline Konsep Penataan & Tata guna lahan & Jenis penggunaan lahan \\
\hline Kawasan & Bentuk dan kelompok bangunan & Skyline dan ciri khas bangunan setempat \\
\hline \multirow[t]{6}{*}{ Pakunegara Tayan } & Ruang terbuka & Intensitas pemanfaatan lahan \\
\hline & Parkir dan sirkulasi & Aksesbilitas dan jalur sirkulasi kawasan \\
\hline & Tanda-tanda & $\begin{array}{l}\text { Pengikat dan pembeda kawasan dengan } \\
\text { kawasan lainnya }\end{array}$ \\
\hline & Jalur pejalan kaki & $\begin{array}{l}\text { Kontinuitas pedestrian di tepi sungai dan } \\
\text { sekitar kawasan }\end{array}$ \\
\hline & Pendukung kegiatan & $\begin{array}{l}\text { Even-even yang berlangsung rutin, bulanan } \\
\text { maupun tahunan }\end{array}$ \\
\hline & Preservasi & $\begin{array}{l}\text { Visibilitas kawasan sebagai frontyard } \\
\text { terhadap sungai Kapuas }\end{array}$ \\
\hline
\end{tabular}

Sumber: Hasil Penelitian, 2019

\section{HASIL DAN PEMBAHASAN}

\section{Analisa Kondisi Eksisiting}

Hasil survey di lapangan menunjukkan keragaman dari tata guna lahan kawasan secara mikro, dimana fungsi pemanfaatan lahan berupa perkantoran, pertokoan, café, bengkel servis, zona pendidikan, zona perdagangan dan jasa, zona budaya, zona ruang terbuka hijau dan zona sempadan sungai. Zona perumahan merupakan yang paling dominan, dengan tingkat kepadatan tinggi dan kepadatan sedang, sedangkan zona perdagangan dan jasa sangat dominan di koridor jalan raya Tayan-Meliau. Fungsi pemanfaatan di zona ruang terbuka terdiri dari: pemakaman, lapangan olahraga, hutan kebun dan lahan kosong. Kondisi zona sempadan sungai saat ini ditempati sebagai hunian dengan tingkat kepadatan yang rendah. Kondisi Eksisiting ditunjukkan pada gambar di bawah ini.

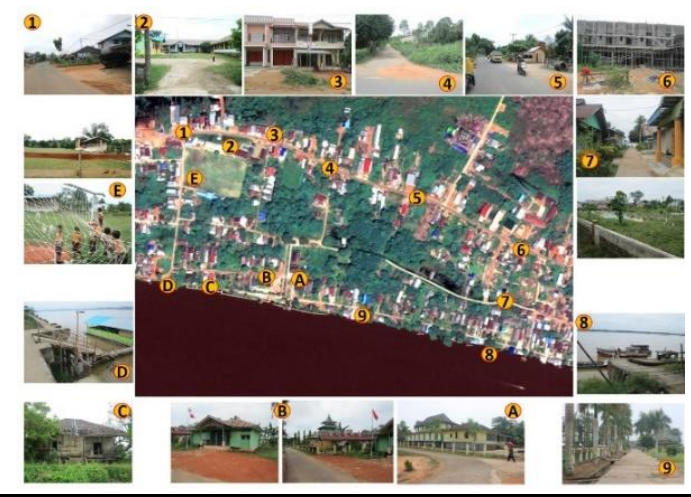

\section{Gambar 3. Kondisi Eksisting Kawasan Keraton Pakunegara Tayan}

Tata bangunan pada kawasan Keraton Tayan dapat dibedakan menjadi dua area deliniasi berdasarkan karakteristiknya, yaitu area inti cagar budaya Keraton Tayan dan area sekitar cagar budaya Keraton Tayan. Area inti cagar budaya Keraton Tayan memiliki bangunan dengan ketinggian satu lantai. Keseluruhan bangunan memiliki orientasi yang sama, yaitu memiliki citra bangunan khas kekeratonan Tayan. Bangunan pada area inti cagar budaya Keraton Tayan memiliki jarak yang berjauhan (Keraton dan Masjid), sehingga ruang terbuka dan bangunan dapat berfungsi secara maksimal. Area sekitar cagar budaya 
Keraton Pakunegara Tayan memiliki bangunan dengan ketinggian satu hingga dua lantai. Beberapa bangunan memiliki orientasi yang tidak sama serta memiliki citra bangunan masing-masing, sehingga dapat dikatakan secara keseluruhan bahwa bangunan pada area sekitar inti cagar budaya Keraton Tayan tidak memiliki satu kesatuan yang utuh.

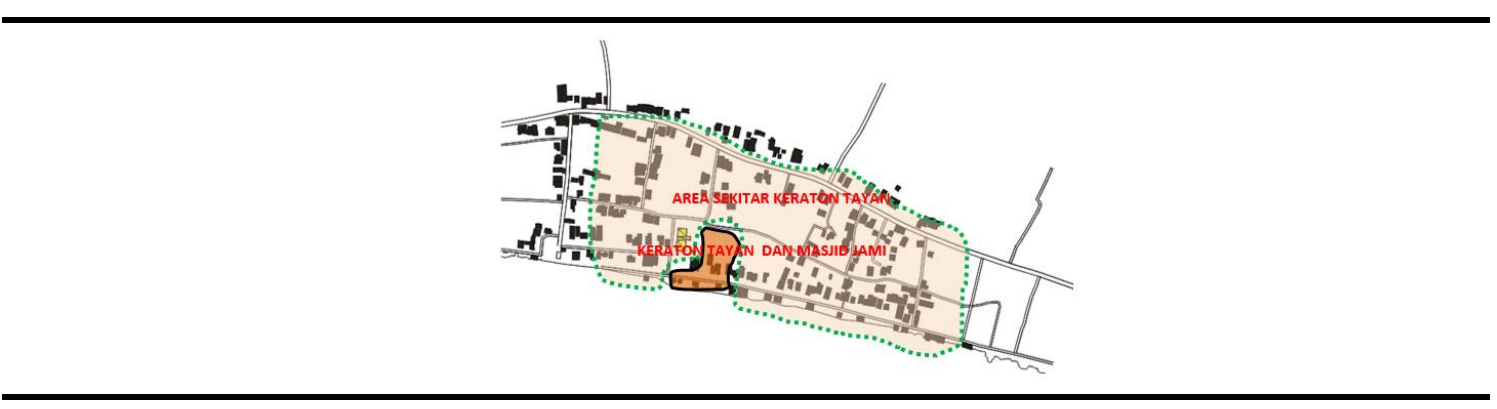

\section{Gambar 4. Area Inti Cagar Budaya dan Area Sekitar Inti Cagar Budaya}

Dalam kondisinya kawasan ini terancam dalam kawasan pertumbuhan tinggi, khususnya pembangunan yang dominan mengambil daerah tepian sungai. Pembangunan yang terjadi di sekitar kawasan keraton tidak mempertimbangkan sungai sebagai potensi yang ada dalam kawasan. Banyak bangunan yang berdiri dengan sungai sebagai bagian belakang bangunan. Keraton Pakunegara Tayan yang terletak di pinggiran sungai dapat menjadi "trigger" kawasan dan sekitarnya untuk memperkuat kedudukan sungai sebagai arah hadap depan bangunan. Pelestarian lingkungan kawasan dan daerah tepian sungai tetap menjadi perhatian utama sebelum melakukan proses penataan fisik kawasan.

Untuk jalur yang menyeberangi sungai saat ini hanya ada satu jembatan yang menghubungkan desa yang ada di Kota Tayan. Sedangkan untuk masyarakat yang tinggal di desa Pulau menggunakan sarana transportasi air yaitu perahu atau kapal kecil untuk menuju ke arah kota. Namun dengan dibukanya jalur penghubung baru yaiu Jembatan Tayan dengan panjang 1,4 km tidak menutup kemungkinan sirkulasi jalur penghubung serta aksesbilitas menuju dari dan ke kota Tayan akan semakin mudah, masyarakat dari desa Pedalaman, desa Kawat dan desa Pulau akan saling terhubung satu sama lain. Bukan hanya masyarakat yang tinggal pada kawasan tepian sungai Kapuas atau masyarakat Tayan tetapi dengan adanya jembatan ini akses menuju daerah lain pun akan semakin mudah.

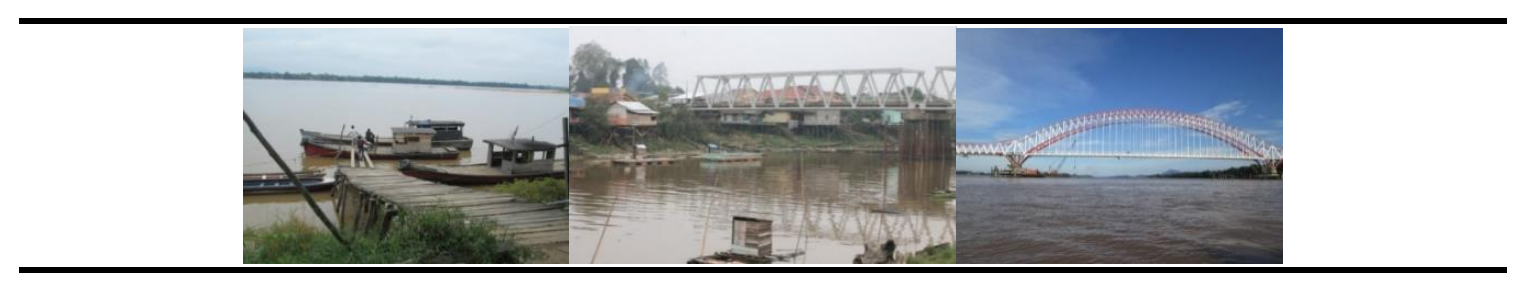

Gambar 5. Infrastuktur kota Tayan

Sebuah analisa jalur penghubung pada kawasan Keraton Pakunegara Tayan dilakukan dengan menggunakan analisa space syntax, menunjukkan tinggi rendahnya nilai integrasi ruang jalan kawasan berdasarkan keterkaitan antar ruang yang saling berhubungan baik secara langsung maupun tidak langsung. Analisa ditunjukkan melalui peta garis-garis aksial yang memiliki ragam nilai integrasi yang tinggi dan rendah berdasarkan gradasi warna. Semakin tinggi nilai integrasi suatu ruang, warna garis semakin merah dan sebaliknya jika semakin rendah nilai integrasi maka warna garis semakin biru. 


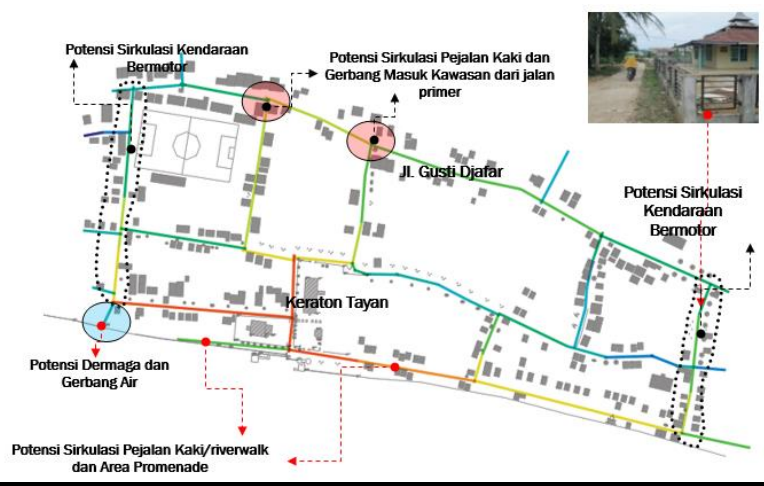

Gambar 6. Garis aksial yang meunjukkan tingkat integrasi jalur-jalur penghubung di dalam kawasan Keraton Pakunegara Tayan

Seperti yang terlihat pada gambar di atas, kawasan Keraton Tayan diapit oleh garisgaris berwarna merah dengan nilai integrasi tinggi yang merupakan jalan lingkungan keraton. Semakin ke arah sungai gradasi warna berubah dari warna biru ke warna merah. Ini menunjukkan bahwa semakin ke dalam kawasan Keraton Tayan dan Sungai Kapuas memiliki nilai integrasi yang tinggi dengan nilai integrasi yang paling tinggi berada di sepanjang tepi sungai. Nilai integrasi yang rendah dengan warna hijau dan biru ini terlihat baik di bagian utara yaitu di jalan utama J1. Gusti Djafar, sedangkan kondisi yang sama ditunjukkan pada bagian sisi barat dan timur kawasan.

Nilai integrasi yang rendah menunjukkan area di sekitar kawasan keraton Tayan relatif kurang terhubung dengan lingkungan sekitarnya, hasil yang sama ditunjukkan dari hasil survey sebelumnya. Untuk meningkatkan nilai integrasi di sepanjang tepi sungai dan lingkungan sekitar keraton Tayan maka perlu adanya hubungan dengan lingkungan yang lebih global, yakni koneksi langsung dengan jalan-jalan utama dan jalinan jalan antar kampung yang saling berseberangan. Dengan demikian area-area di dalam kawasan akan semakin terintegrasi dan meningkat nilai aksesbilitasnya. Dengan adanya analisa jalur penghubung dapat menentukan konsep yang tepat untuk sirkulasi pada kawasan penelitian.

\section{Konsep Penataan Kawasan keraton Pakunegara Tayan}

Dari hasil amatan dan analisa sebelumnya dapat dikembangkan konsep penataan Kawasan Keraton Pakunegara Tayan, sebelum masuk ke ranah konsep perlu adanya penentuan visi dan misi pada kawasan supaya keberhasilan penanganan kawasan sesuai yang diharapkan. Adapun visi yang diimplementasikan terhadap konsep penataan tersebut adalah "Mewujudkan Kawasan Keraton Pakunegara Tayan Sebagai Kawasan Pusaka Tepian Air yang Berkelanjutan untuk Mendukung Kegiatan Budaya dan Pariwisata". Dari visi tersebut, dapat dirumuskan beberapa misi yang akan menjadi dasar bagi konsep penataan kawasan Keraton Pakunegara Tayan, Misi tersebut antara lain: a) Membentuk dan melestarikan lingkungan kawasan Keraton Pakunegara Tayan sebagai kawasan pusaka tepian air yang berkelanjutan, b) Menciptakan kawasan yang nyaman, manusiawi, ramah lingkungan dan pemberdayaan masyarakat dalam rangka pelestarian budaya dan kegiatan pariwisata, c) Membentuk dan memperkuat citra kawasan sebagai kawasan budaya dan bersejarah (heritage).

Melihat potensi dan hambatan yang ada pada kawasan maka konsep yang diusulkan untuk diterapkan di kawasan perencanaan adalah Pembangunan yang Adaptif (Adaptive Development) dan Pembangunan yang Terpadu (Integrated Development). Penjabaran 2 (dua) konsep tersebut dapat dilihat pada tabel 3.

2 (dua) konsep tersebut diterapkan pada kawasan Keraton Pakunegara Tayan, dengan mengadopsi teori urban design process dari Hamid Shirvani. 


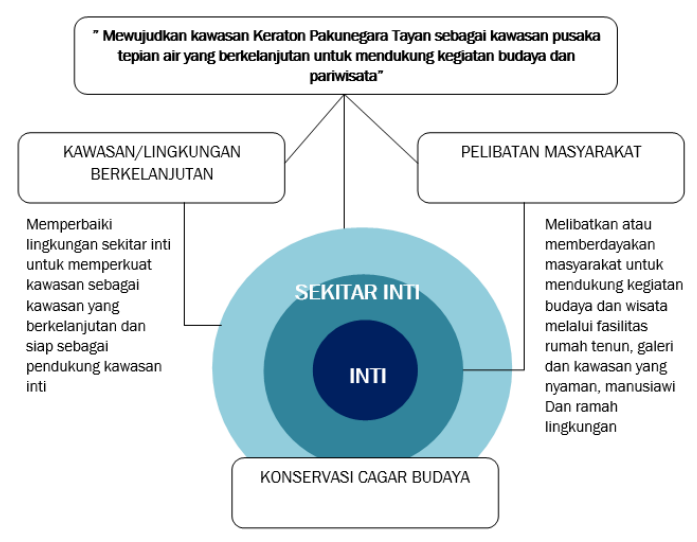

Gambar 7. Kaitan Visi Dan Misi Terhadap Tema Kawasan

Tabel 3. Visi, Misi dan Konsep Penataan Kawasan Keraton Pakunegara Tayan

\begin{tabular}{|c|c|c|c|}
\hline \multirow[t]{2}{*}{ Visi } & \multirow[t]{2}{*}{ Misi } & \multicolumn{2}{|c|}{ Konsep } \\
\hline & & Adaptive Development & Integrated Development \\
\hline \multirow{3}{*}{$\begin{array}{l}\text { Mewujudkan } \\
\text { kawasan Keraton } \\
\text { Pakunegara Tayan } \\
\text { sebagai kawasan } \\
\text { pusaka tepian air } \\
\text { yang berkelanjutan } \\
\text { untuk mendukung } \\
\text { kegiatan budaya dan } \\
\text { pariwisata }\end{array}$} & $\begin{array}{l}\text { Membentuk dan melestarikan } \\
\text { lingkungan kawasan Keraton } \\
\text { Pakunegara Tayan sebagai } \\
\text { kawasan pusaka tepian air } \\
\text { yang berkelanjutan }\end{array}$ & $\begin{array}{l}\text { - Adaptive housing and } \\
\text { settlement } \\
\text { - Adaptive re-use of } \\
\text { communal open space } \\
\text { - Adaptive green space }\end{array}$ & $\begin{array}{l}\text { Integrated land use } \\
\text { Integrated linkage structure } \\
\text { Integrated utility }\end{array}$ \\
\hline & $\begin{array}{l}\text { Menciptakan kawasan yang } \\
\text { nyaman, manusiawi, ramah } \\
\text { lingkungan dan } \\
\text { pemberdayaan masyarakat } \\
\text { dalam rangka pelestarian } \\
\text { budaya dan kegiatan } \\
\text { pariwisata. }\end{array}$ & $\begin{array}{l}\text { - Adaptive riverside walk } \\
\text { - Adaptive commercial } \\
\text { and culture based } \\
\text { community }\end{array}$ & \\
\hline & $\begin{array}{l}\text { Membentuk dan memperkuat } \\
\text { citra kawasan sebagai } \\
\text { kawasan budaya dan } \\
\text { bersejarah (heritage) }\end{array}$ & $\begin{array}{l}\text { Conservation (heritage } \\
\text { building) }\end{array}$ & \\
\hline
\end{tabular}

Sumber: Hasil Penelitian, 2019

\section{Tata Guna Lahan (Land Use)}

Tata guna lahan pada Kawasan Keraton Pakunegara Tayan memiliki dua area yang berbeda dalam penggunaan lahannya. Secara keseluruhan kawasan dibagi menjadi 8 (delapan) blok yang masing-masing terdiri dari sub blok kecil antara lain zona cagar budaya, zona permukiman, zona perdagangan dan jasa, zona pendidikan, dan zona ruang terbuka hijau/tepian/sempadan sungai.Untuk itu, analisis dibagi menjadi dua deliniasi berdasarkan karakteristik fungsi lahannya, yaitu area inti cagar budaya Keraton Pakunegara Tayan (blok G) dan area sekitar inti cagar budaya Keraton Pakunegara Tayan (blok A,B,C,D,E,F,H). Blok yang memiliki tepian/sempadan sungai antara lain blok $F, G$ dan $H$. Blok lain yang tidak berhadapan dengan tepian sungai lebih diperuntukan dalam program penanganan tata bangunan dan lingkungan serta koridor hijau. 


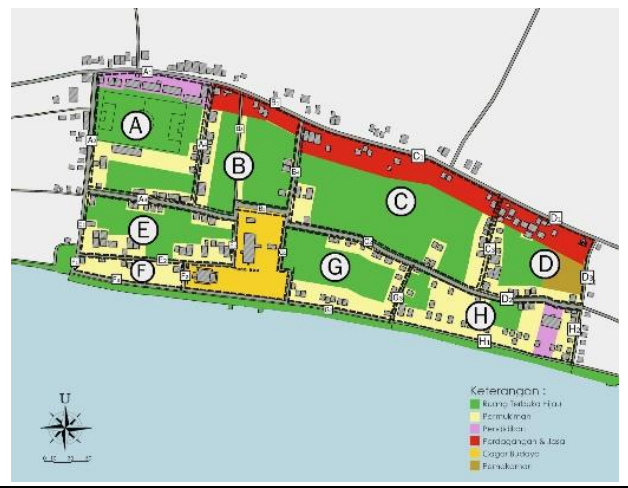

Gambar 8. Konsep Tata Guna Lahan Area Inti dan Sekitar Inti

\section{Bentuk dan Massa Bangunan (Building Form and Massing)}

Keraton Pakunegara Tayan sebagai hirarki kawasan. Pengaturan komposisi massa bangunan sekitar keraton yang teratur dan pembentuk hirarki kawasan. Perencanaan permukiman pada blok F, G dan $\mathrm{H}$ diarahkan untuk berorientasi ke sungai. Permukiman yang sudah terletak di sempadan sungai akan mengalami relokasi dan ditempatkan pada sisi blok H. Sempadan sungai harus bebas dari fisik permukiman. Komposisi permukiman ini sebagai pembentuk hirarki bagi kawasan cagar budaya. Pada wilayah perencanaan sebagian besar bangunan permukiman permanen dan sisanya semi permanen dan non permanen. Kepadatan bangunan perumahan diarahkan pada tingkat sedang. Ketinggian bangunan pada permukiman penduduk diarahkan pada ketinggian 1-2 lantai dengan ketinggian maksimal 4 - 8 meter (belum termasuk atap). Dalam kaitannya dengan komposisi garis langit maka enclosure yang diharapkan adalah pada area tepian sungai yang mengapit Keraton Pakunegara Tayan dan Masjid Jami' tetap memiliki ketinggian puncak pada atap bangunan Keraton Pakunegara Tayan. Sedangkan untuk ketinggian bangunan pada perdagangan dan jasa maka ketinggian maksimal 3 lantai.

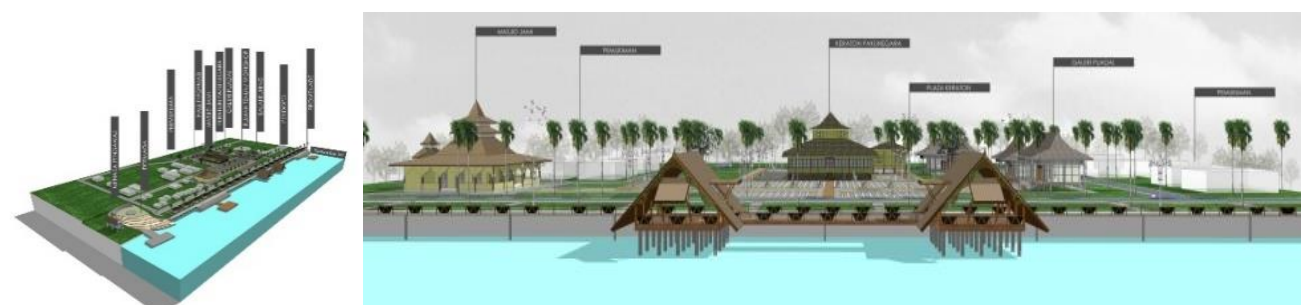

Gambar 9. (kiri) Komposisi Permukiman Terhadap Keraton, Letak Keraton Sebagai Sumbu dan Hirarki Kawasan (kanan)

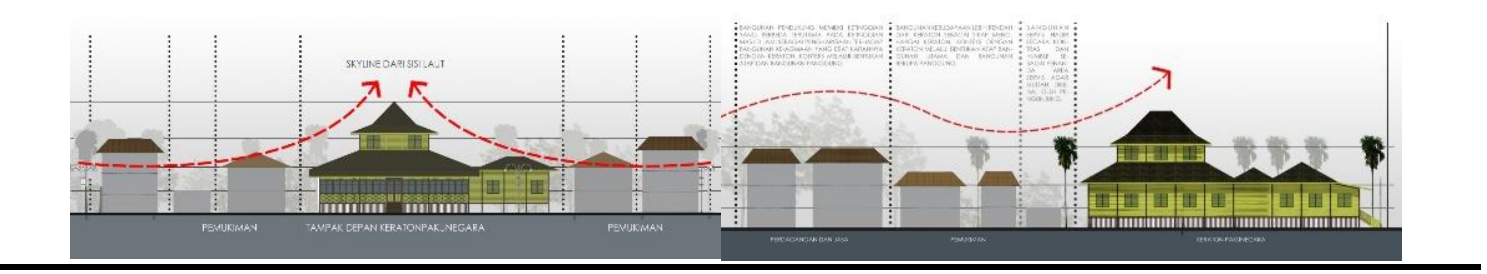

Gambar 10. Pengaturan Ketinggian (Skyline) Dari Sisi Sungai dan Darat 


\section{Sirkulasi dan Parkir (Circulation and Parking)}

Jalan pada jalur pedestrian sesuai dengan kondisi eksisting. Pedestrian direncanakan pada sisi koridor jalan arteri utama dan tipe jalan 2 yang dimulai akses dari blok A menuju ke blok D. Sementara untuk jalur pedestrian, peletakan lampu jalan, jalur hijau, dan parkir dibuat pada sisi kiri dan kanan jalan yang disertai dengan saluran drainase tertutup dan terbuka. Penggunaan bahan paving berwarna memungkinkan untuk mengamankan titik-titik konflik antara pejalan kaki, sepeda, dan lalu lintas kendaraan. Menyediakan tempat duduk di beberapa titik sepanjang rute. Konsep dasar sirkulasi pada kawasan Keraton Pakunegara Tayan pada jalur entrance utama di lajur blok A hingga blok D masih memungkinkan untuk pengembangan lebar jalan untuk 2 kendaraan roda empat. Pelebaran tersebut disisinya penambahan pedestrian selebar 1 meter. Parkir kendaraan sewaktu-waktu dapat menggunakan parkir on-street. Rute sirkulasi kendaraan didalam kawasan dibagi lajur satu arah untuk kendaraan satu mobil, khususnya bagi pengunjung. Pola sirkulasi ini diatur agar tidak mengganggu akses utama atau halaman utama menuju Keraton Pakunegara Tayan.

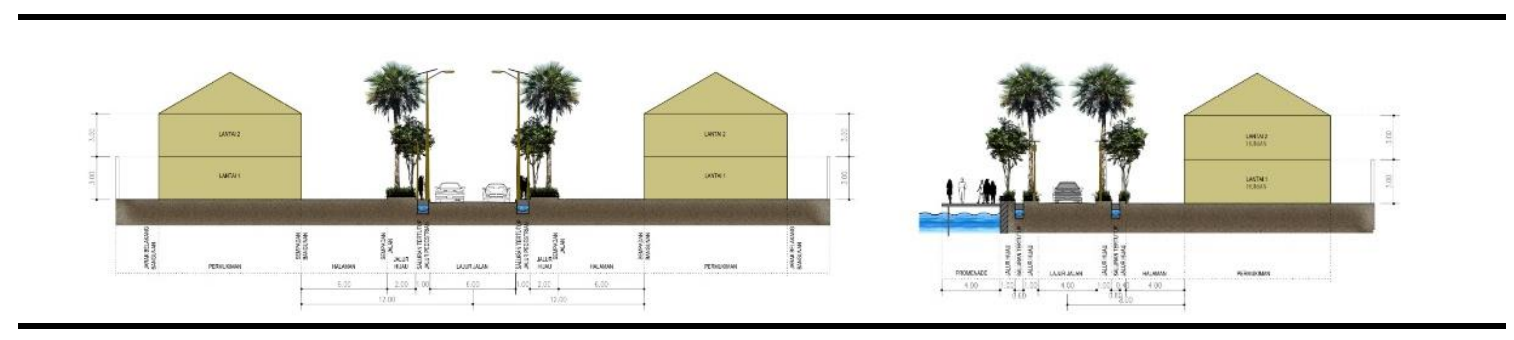

Gambar 11. Penggal Sirkulasi di Kawasan Keraton Pakunegara Tayan

\section{Ruang Terbuka (Open Space)}

Adapun konsep sistem ruang terbuka dan tata hijau di kawasan perencanaan adalah Penataan Koridor Sungai, Kawasan tepian sungai di blok F, blok G, Blok H diarahkan menjadi kawasan Ruang Terbuka Hijau (RTH) dengan adanya koridor hijau kawasan. koridor sungai diproyeksikan menjadi ruang sosial warga lokal dan pengunjung sekaligus daya tarik pusat kegiatan. Program-program pengembangan yang diuusulkan antara lain: 1) Koridor hijau tepian sungai, 2) Koridor hijau sepanjang sisi jalan arteri utama dan lingkungan kawasan, 3) Penataan talud untuk promenade kawasan.
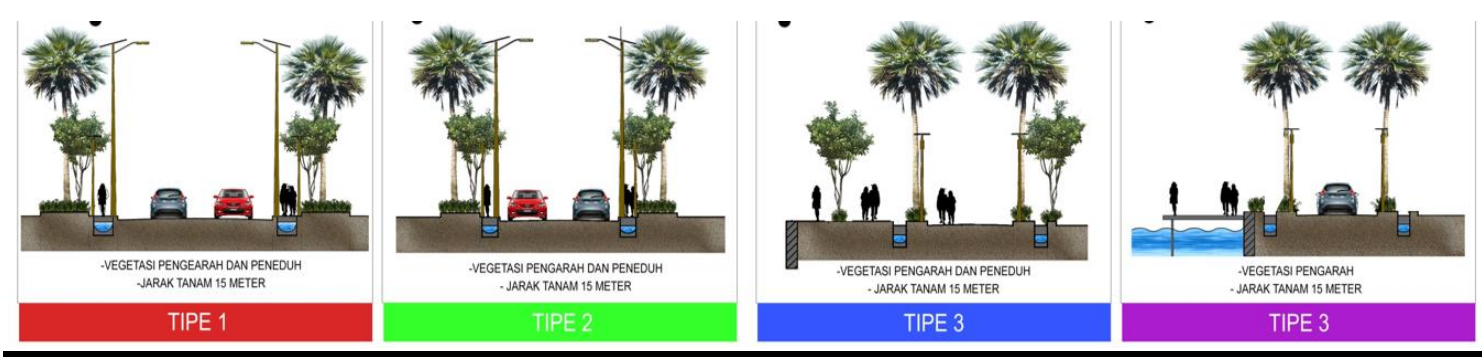

Gambar 12. Konsep Ruang Terbuka dan Tata Hijau Kawasan

\section{Jalur Pedestrian (Pedestrian Ways)}

Area Pedestrian sangat diperlukan untuk menunjang aktivitas pejalan kaki baik dari area parkir maupun dari area jalan baik depan ataupun belakang bangunan. Konsep pedestrian yang diusulkan dalam desain bertujuan sebagai pembeda antara jalan sirkulasi kendaraan, area parkir dan pedestrian itu sendiri. Penggunaan material yang berbeda dan 
pemakaian pola dari material yang berbeda juga diusulkan. Pola-pola pedestrian ini akan memberi ciri khusus keberadaannya. Pedestrian diatur sepanjang jalan arteri utama maupun jalan lingkungan di kawasan Keraton Pakunegara Tayan.

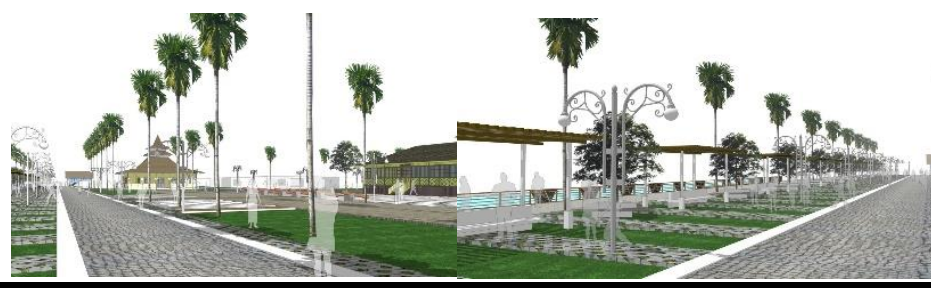

Gambar 13. Konsep Suasana Jalur Pedestrian

\section{Aktifitas Pendukung (Activity Support)}

Konsep aktifitas pendukung pada kawasan ini dipusatkan pada Promenade di kawasan tepian sungai kawasan Keraton Pakunegara Tayan yang direncanakan memiliki beraneka fungsi, seperti rekreatif, budaya, riverwalk dan sosial. Promenade ini dapat digunakan sebagai ruang aktivitas berupa ruang komunal dan ruang yang bebas dari kendaraan bermotor. Pelibatan masyarakat setempat untuk berjualan temporer di kawasan promenade secara kreatif. Promenade ini nantinya direncanakan sebagai berikut :

- Ruang terbuka dan jalur hijau selebar (menyesuaikan kondisi tepian sungai) dan letaknya sesuai dengan garis sempada sungai (GSS).

- Area untuk street furniture adalah pada jalur hijau atau ruang utilitas sepanjang tidak mengganggu facade bangunan.

- Fasilitasnya berupa bangku taman dan penerangan

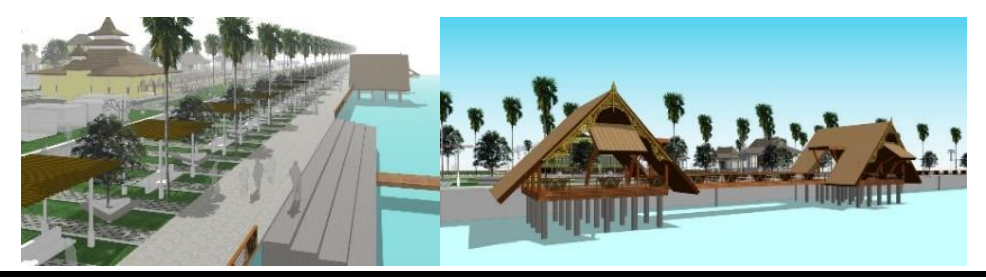

Gambar 14. Konsep Suasana Promenade

\section{Penandaan (Signage)}

Agar tidak terlepas dari lingkungan sekitarnya maka konsep penataan Kawasan Keraton Pakunegara Tayan perlu ditampilkan unsur-unsur bangunan dan Lingkungann yang terhubung dengan kawasan sekitarnya yang berfungsi sebagai penanda konektivitas sehingga perlu ditampilkan:

- Pada area tepian sungai fungsi blok dan komponen fisik antara lain tepian sungai, disain taman, promenade serta perkerasannya perlu disamakan disainnya sehingga menjadi satu kesatuan suasana.

- Interelation space ( ruang yang menerus merupakan unity hubungan antar blok dalam kawasan prasarana untuk sirkulasi yang diperlukan adalah jaringan jalan dan jaringan pejalan kaki, sebagai penandanya direncanakan jaringan jalan dan pejalan kaki pada tepian sungai yang menerus. 
- Lingkage antara Kawasan permukiman, kawasan cagar budaya dengan kawasan tepian sungai ditandai dengan fungsi jalan baru, sebagai akses menuju kawasan secara keseluruhan.

- Untuk menegaskan kawasan sebagai area riverwalk maka pada titik-titik (node) yang dianggap kuat dan berpotensi menjadi gerbang masuk kawasan riverwalk yakni dengan memberikan penanda berupa gerbang/pintu masuk.

- Elemen penanda berupa gerbang masuk harus jelas keberadaanya secara visual dengan mempertimbangkan visibilitasnya baik dari sisi pejalan kaki maupun oleh pengendara kendaraan bermotor.

- Tata informasi untuk memberikan petunjuk keberadaan fasilitas tertentu diletakkan di area sedemikian rupa dapat diakses secara visual terutama oleh pejalan kaki. Khususnya menunjuk pada keberadaan jalur riverwalk maka elemen penanda dengan fungsi pengarah atau directional.

- Tata rambu pengarah diletakkan pada area yang dapat diakses secara visual oleh pengendara kendaraan.

Rambu petunjuk ditempatkan pada sisi jalan, pemisah jalan, atau di atas ruang milik jalan sebelum tempat, daerah atau lokasi yang ditunjuk.

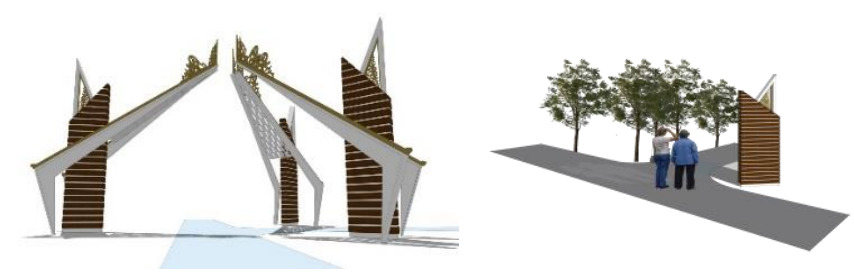

Gambar 15. Konsep Gerbang Masuk Kawasan

\section{Pemeliharaan/Pelestarian (Preservation)}

Konsep pemeliharaan/pelestarian Kawasan Keraton Pakunegara Tayan difokuskan pada area inti kawasan yaitu Keraton Pakunegara Tayan, konsep yang ditampilkan yaitu:

- Mempertegas kedudukan bangunan cagar budaya terhadap kawasan sekitar

- Menciptakan ruang komunal untuk mempertegas kesan landmark bangunan

- Melestarikan bangunan cagar budaya

- Integrasi kawasan inti dengan kawasan sekitar inti

Adapun program konsep preservasi tersebut diaplikasikan pada 3 bangunan cagar budaya. Untuk Keraton Pakunegara Tayan program pengembangan adalah dilakukannya preservasi bangunan. Masjid Jami' dilakukan proses restorasi masjid. Sedangkan untuk plaza Keraton Pakunegara Tayan dilakukan tahapan-tahapan antara lain : a) Memperkuat posisi plaza sebagai ruang komunal dan mempertegas kesan landmark bangunan keraton, b) Dapat digunakan sebagai area pendukung kegiatan budaya, c) Perkerasan yang ramah lingkungan, tanpa pohon (kecuali pohon eksisting) hanya ada di sisi kiri dan kanan plaza, tujuannya untuk mempertegas posisi keraton.

\section{DISKUSI}

Penataan bangunan dan lingkungan banyak sekali dibahas pada penelitian-penelitian sebelumnya, karena semakin populernya isu-isu perkotaan dan masyarakat lebih kritis terhadap isu tata ruang. Keragaman yang berpengaruh terhadap pembentukan sebuah kota, pada akhirnya akan mempengaruhi tata cara mengatur kota itu sendiri. RTRW saja tidak cukup dalam mengakomodasi kebutuhan masyarakat kota, RTRW sebagai perangkat 
pengatur yang berlaku secara umum, memerlukan peraturan pelaksana yang dapat menguraikan lebih rinci kebutuhan warga kota yang beragam (Nurfitriati, 2015). Hasil dari penelitian-penelitian tersebut ada yang berupa arahan konsep penataan kawasan ataupun identifikasi pemanfaatan ruang kawasan.

Melihat banyaknya penelitian-penelitian mengenai tata bangunan dan lingkungan di beberapa kota di Indonesia, membuat penelitian tentang penataan kawasan terutama area urban menjadi popular. Permasalahan yang ditimbulkan pun beragam, sehingga menghasilkan konsep/arahan ataupun identifikasi permasalahan yang berbeda-beda pula. Focus permasalahan pada penelitian-penelitian sebelumnya juga beraneka ragam mulai dari penataan dan pengendalian bangunan pada area pusat perdagangan jasa, penataan bangunan dan lingkungan yang berbudaya Islam, identifikasi permasalahan pada koridor yang digunakan untuk pedagang kaki lima, penataan bangunan dan lingkungan di wilayah pesisir dan lain-lain. Hasil dari penelitian tersebut sangat membantu penulisan penelitian ini terutama dalam melihat fenomena perkotaan yang menjadi permasalahan tata bangunan dan lingkungan misalnya seperti intensitas pemanfaatan ruang dan lahan yang tidak sesuai fungsi dan tata bangunan lingkungan yang sudah tidak sesuai dengan rencana tata ruang dikarenakan pertumbuhan kota yang semakin sprawl. Dari cara melihat fenomena tersebut penelitian ini bukan hanya mengidentifikasi permasalahan yang terjadi di Kawasan Keraton Pakunegara Tayan tetapi memberikan konsep dan rekomendasi secara 3 dimensional bagaimana Kawasan Keraton Pakunegara Tayan harus berkembang di masa depan, menggali potensi-potensi yang ada tetapi tetap mempertahankan wilayah preservasi dan konservasi yang menjadi citra kawasan ini secara keseluruhan.

Beberapa studi terdahulu yang memiliki kesamaan topik terhadap penelitian ini dilakukan oleh Windriarti Hendrojogi (2008), Zairin Zain dan Azwar Fahmie (2018), Hendrick Suriandjo (2017), Hendra A. Permana (2013), Fendi F. Gobel (2019), serta Ishaq Rizal (2012). Keenam penelitian terdahulu ini akan dikemukakan secara ringkas dalam tabel berikut:

\begin{tabular}{|c|c|c|c|c|}
\hline & Peneliti & $\begin{array}{l}\text { Judul dan Tahun } \\
\text { Penelitian }\end{array}$ & $\begin{array}{c}\text { Metode dan } \\
\text { Lokasi } \\
\text { Penelitian } \\
\end{array}$ & State of the art \\
\hline 1. & $\begin{array}{l}\text { Windriarti } \\
\text { Hendrojogi }\end{array}$ & $\begin{array}{l}\text { Arahan Pengaturan } \\
\text { dan pengendalian } \\
\text { Bangunan di } \\
\text { Kecamatan Pinang } \\
\text { Kota Tangerang } \\
(2008)\end{array}$ & $\begin{array}{l}\text { Metode } \\
\text { Kualitatif } \\
\text { Lokasi: } \\
\text { Kecamatan } \\
\text { Pinang, Kota } \\
\text { Tangerang }\end{array}$ & $\begin{array}{l}\text { Penelitian berfokus pada arahan } \\
\text { pengendalian bangunan di } \\
\text { Kecamatan Pinang Kota } \\
\text { Tangerang. Pengaturan ini } \\
\text { berupa KDB, KLB, dan } \\
\text { ketinggian bangunan. Arahan } \\
\text { tersebut berlaku pada } \\
\text { pemanfaatan lahan antara lain: } \\
\text { Kawasan Perdaganagan Jasa } \\
\text { dan industry eksiisting, } \\
\text { Kawasan perdagangan dan Jasa } \\
\text { Komersial. Industri Rumah } \\
\text { Tangga, Jalur Frontage Toll, } \\
\text { Permukiman Kepadatan Tinggi, } \\
\text { Permukiman Kepadatan } \\
\text { Sedang, Fasilitas Sosial dan } \\
\text { Umum, serta Ruang Terbuka } \\
\text { Hijau }\end{array}$ \\
\hline 2 . & $\begin{array}{l}\text { Ishaq Rizal dan } \\
\text { Abdul Muhyi }\end{array}$ & $\begin{array}{c}\text { Rencana Tata } \\
\text { Bangunan dan } \\
\text { Lingkungan Pada } \\
\text { Kawasan Pusat } \\
\text { Pemerintahan } \\
\text { Kabupaten Pidie Jaya } \\
\text { Propinsi Aceh } \\
\text { (2012) }\end{array}$ & $\begin{array}{l}\text { Metode Survey } \\
\text { dan } \\
\text { pengumpulan } \\
\text { Data } \\
\text { Lokasi: Pusat } \\
\text { Pemerintahan } \\
\text { Kabupaten Pidie } \\
\text { Jaya, Aceh }\end{array}$ & $\begin{array}{l}\text { Penelitian ini meneraPkan lima } \\
\text { elemen citra kota (landmark, } \\
\text { node, path, edge, distrik) dan tata } \\
\text { bangunan yang } \\
\text { merepresentasikan kebutuhan } \\
\text { dan citra masyarakat kabupaten } \\
\text { Pidie Jaya. Ruang kota } \\
\text { diharapkan berorientasi pada } \\
\text { pejalan kaki (pedestrian oriented) }\end{array}$ \\
\hline
\end{tabular}




\begin{tabular}{|c|c|c|c|}
\hline Peneliti & $\begin{array}{c}\text { Judul dan Tahun } \\
\text { Penelitian }\end{array}$ & $\begin{array}{c}\text { Metode dan } \\
\text { Lokasi } \\
\text { Penelitian }\end{array}$ & State of the art \\
\hline & & & $\begin{array}{l}\text { untuk meningkatkan aktivitas } \\
\text { dalam skala manusia. } \\
\text { Penerapan Islam dan budaya } \\
\text { masyarakat Aceh dengan } \\
\text { adanya Mesjid pada gerbang } \\
\text { Utama, dan gaya bangunan } \\
\text { yang mengadopsi arsitektur } \\
\text { tradisional Aceh. }\end{array}$ \\
\hline $\begin{array}{ll}\text { 3. } & \text { Hendra Adi } \\
\text { Permana dan } \\
\text { Prakarsa Yoga }\end{array}$ & $\begin{array}{c}\text { Kajian Pola Tata } \\
\text { Bangunan dan } \\
\text { Lingkungan Serta } \\
\text { Bentuk Bangunan } \\
\text { Kawasan The Reggata } \\
\text { di Pantai Mutiara } \\
\text { Jakarta } \\
\text { (2013) }\end{array}$ & $\begin{array}{l}\text { Metode kualitatif } \\
\text { pendekatan } \\
\text { berbasis teori } \\
\text { Lokasi: Pantai } \\
\text { Mutiara, Jakarta } \\
\text { Utara }\end{array}$ & $\begin{array}{l}\text { Penelitian ini mengidentifikasi } \\
\text { Pola Tata Ruang Luar } \\
\text { (Masterplan) dan Tata Ruang } \\
\text { dalam (Denah) pada Kawasan } \\
\text { Superblok The Regatta, } \\
\text { mengidentifikasi bentuk dan } \\
\text { tampak bangunan Kawasan } \\
\text { Superblok The Regatta, } \\
\text { menemukan karakteristik pola } \\
\text { tatanan bangunan dan } \\
\text { lingkungan serta bentuk } \\
\text { bangunan Kawasan Superblok } \\
\text { The Regatta. } \\
\text { Kesimpulan Penelitian ini } \\
\text { bahwa Kawasan Regatta } \\
\text { sebagai ikon baru atau salah } \\
\text { satu landmark kota pada } \\
\text { kawasan Utara Jakarta. Karena } \\
\text { setelah dianalisa memiliki scale } \\
\text { on plan, distortion dan focal point } \\
\text { yang sangat baik serta sudah } \\
\text { sesuai dengan teori Town Scape } \\
\text { Gordon Cullen. }\end{array}$ \\
\hline $\begin{array}{ll}\text { 4. } & \text { Hendrik S. } \\
\text { Suriandjo }\end{array}$ & $\begin{array}{c}\text { Kajian Rencana Tata } \\
\text { Bangunan dan } \\
\text { Lingkungan (RTBL) } \\
\text { Kawasan Pusat Kota } \\
\text { Tilamuta } \\
\text { (2017) }\end{array}$ & $\begin{array}{l}\text { Metode } \\
\text { Deskriptif } \\
\text { kualitatif } \\
\text { Lokasi: Kota } \\
\text { Tilamuta, } \\
\text { Kabupaten } \\
\text { Boalemo }\end{array}$ & $\begin{array}{l}\text { Penelitian ini sebagai } \\
\text { representasi arahan masterplan } \\
\text { Tilamuta Kota Pantai dan } \\
\text { Arahan RTRW Boalemo 2009- } \\
\text { 2029, yang menghasilkan } 4 \\
\text { (empat) tema rencana: Blok A } \\
\text { sebagai RTH dan Fasilitas } \\
\text { Pelayanan } \\
\text { Publik/Pemerintahan, Blok B } \\
\text { sebagai Fasilitas public dan jasa } \\
\text { perdagangan modern, Blok C } \\
\text { sebagai Segmen jasa } \\
\text { perdagangan modern dan } \\
\text { Hunian Terencana, dan Blok D } \\
\text { sebagai fasilitas rekreasi dan } \\
\text { perdagangan modern }\end{array}$ \\
\hline $\begin{array}{l}\text { 5. Zairin Zain dan } \\
\text { Azwar Fahmie }\end{array}$ & $\begin{array}{c}\text { Identifikasi Aktifitas } \\
\text { Mendirikan Bangunan } \\
\text { Dalam Pemanfaatan } \\
\text { Ruang Koridor Jalan } \\
\text { Kom Yos Sudarso } \\
\text { Pontianak } \\
\text { (2018) }\end{array}$ & $\begin{array}{l}\text { Metode } \\
\text { Deskriptif } \\
\text { Lokasi: Koridor } \\
\text { Jalan KomYos } \\
\text { Sudarso Kota } \\
\text { Pontianak }\end{array}$ & $\begin{array}{l}\text { Penelitian ini menggambarkan } \\
\text { secara detail mengenai aktivitas } \\
\text { mendirikan bangunan di } \\
\text { wilayah pengamatan. Variabel } \\
\text { yang diamati tekait dengan } \\
\text { aktivitas mendirikan bangunan } \\
\text { yang memanfaatkan ruang di } \\
\text { sepanjang koridor Jalan Kom. } \\
\text { Yos sudarso Pontianak antara } \\
\text { lain: fungsi bangunan, } \\
\text { kegunaan bangunan, jumlah } \\
\text { lantai bangunan, serta jenis } \\
\text { konstruksi bangunan. } \\
\text { Selanjutnya menganalisis }\end{array}$ \\
\hline
\end{tabular}




\begin{tabular}{|c|c|c|c|}
\hline Peneliti & $\begin{array}{l}\text { Judul dan Tahun } \\
\text { Penelitian }\end{array}$ & $\begin{array}{c}\text { Metode dan } \\
\text { Lokasi } \\
\text { Penelitian }\end{array}$ & State of the art \\
\hline & & & $\begin{array}{l}\text { kesesuaian bangunan tersebut } \\
\text { dengan peraturan penataan } \\
\text { ruang dan bangunan khususnya } \\
\text { kesesuaiannya dengan } \\
\text { peraturan penataan RMJ dan } \\
\text { GSB di wilayah pengamatan. } \\
\text { Hasilnya adalah banyak } \\
\text { bangunan yang menyimpang } \\
\text { serta melanggar peraturan yang } \\
\text { ada, dengan demikian } \\
\text { bangunan yang didirikan } \\
\text { tersebut tidak sesuai ketentuan } \\
\text { dan melanggar peraturan } \\
\text { peizinan bangunan. }\end{array}$ \\
\hline $\begin{array}{ll}\text { 6. Fendi Faizal } \\
\text { Gobel }\end{array}$ & $\begin{array}{c}\text { Konsep Penataan } \\
\text { Kawasan Permukiman } \\
\text { Desa lemito } \\
(2019)\end{array}$ & $\begin{array}{l}\text { Metode } \\
\text { Deskriptif } \\
\text { Kualitatif } \\
\text { Lokasi: Desa } \\
\text { Lemito, } \\
\text { Kabupaten } \\
\text { Pohuwato }\end{array}$ & $\begin{array}{l}\text { Penelitian ini berfokus pada } \\
\text { perumusan konsep penataan } \\
\text { desa Lemito dengan visi } \\
\text { menciptakan Kawasan desa } \\
\text { Lemito yang berdaya dan } \\
\text { berbudaya dalam mewujudkan } \\
\text { desa Lemito sebagai kawasan } \\
\text { permukiman yang } \\
\text { berkelanjutan. Visi ini diperkuat } \\
\text { pada aspek-aspek: Bangunan } \\
\text { Gedung, Jalan Lingkungan, } \\
\text { Drainase Lingkungan, Air } \\
\text { Minum, Air Limbah, } \\
\text { Persampahan, Bahaya } \\
\text { Kebakaran, Bahaya Pasang } \\
\text { surut Air Laut, dan Ruang } \\
\text { Terbuka Hijau. }\end{array}$ \\
\hline $\begin{array}{l}\text { 7. Dian Perwita Sari } \\
\text { dan M. Ridha } \\
\text { Alhamdani }\end{array}$ & $\begin{array}{c}\text { Arahan Penataan } \\
\text { Bangunan dan } \\
\text { Lingkungan Pada } \\
\text { Kawasan Keraton } \\
\text { Pakunegara Tayan } \\
\text { Kabupaten Sanggau } \\
\text { Kalimantan Barat } \\
\text { (2020) }\end{array}$ & $\begin{array}{l}\text { Metode } \\
\text { Deskriptif } \\
\text { Kualitatif } \\
\text { Lokasi: Kawasan } \\
\text { Keraton } \\
\text { Pakunegara } \\
\text { Tayan, } \\
\text { Kabupaten } \\
\text { Sanggau }\end{array}$ & $\begin{array}{l}\text { Penelitian ini menghasilkan } \\
\text { konsep, arahan dan } \\
\text { rekomendasi untuk penataan } \\
\text { tata bangunan dan lingkungan } \\
\text { di Kawasan Keraton } \\
\text { Pakunegara Tayan. Konsep } \\
\text { penataan dibuat sinergi dengan } \\
\text { visi dan misi kawasan yaitu } \\
\text { "Mewujudkan kawasan } \\
\text { Keraton Pakunegara Tayan } \\
\text { sebagai kawasan pusaka tepian } \\
\text { air yang berkelanjutan untuk } \\
\text { mendukung kegiatan budaya } \\
\text { dan pariwisata". Dimana visi } \\
\text { dan misi tersebut dirangkum } \\
\text { menjadi } 2 \text { (dua) konsep utama } \\
\text { yang kemudian konsep-konsep } \\
\text { tersebut diuraikan melalui } \\
\text { elemen-elemen urban dan } \\
\text { menjadikan arahan penataan } \\
\text { tersebut makin memperkuat } \\
\text { keberadaan Keraton } \\
\text { Pakunegara Tayan sebagai ikon } \\
\text { dan cagar budaya di Kota } \\
\text { Tayan. }\end{array}$ \\
\hline
\end{tabular}

Sumber: dikonstruksikan ulang oleh Penulis, 2020

Dapat dilihat dari table di atas persamaan studi terdahulu dengan penelitian ini terletak pada topik yang diangkat yaitu arahan penataan tata bangunan dan lingkungan, 
persamaan kedua adalah metode penelitian yang digunakan menggunakan pendekatan deskriptif kualitatif dengan teknik survei, data-data sekunder, observasi yang kemudian datadata tersebut dintepretasikan secara naratif dan kemudian merumuskan kesimpulan serta rekomendasi. Sedangkan perbedaan penelitian ini dengan penelitian sebelumnya terletak pada lokus yang diteliti dan state of the art.

Keunggulan penelitian ini pada focus penelitian yang dikaji yaitu kawasan bangunan yang tumbuh pada area konservasi sungai dan bangunan cagar budaya dimana lokus kawasan yang berada di tepi sungai dan bagaimana potensi-potensi kawasan Keraton Pakunegara Tayan dapat ditingkatkan untuk menambah nilai dan menjadi model percontohan kawasan konservasi tepi sungai dan cagar budaya lainnya. Studi ini menitikberatkan kepada penataan di sekitar Kawasan Keraton Pakunegara Tayan dan area waterfront supaya memperkuat keberadaan keraton ini yang hampir punah ditelan jaman tanpa merusak bangunan eksisting yang ada. Arahan penataan pada area waterfront dilakukan dengan cara beutifikasi dengan penambahan fungsi kegiatan tahunan seperti mandi bedil kerajaan, mandi keris, perang ketupat dan upacara tolak bala. Penelitian ini berfokus untuk mensinergikan Kawasan Keraton Pakunegara Tayan dan lingkungan sekitarnya dalam tiga tahapan yang sesuai dengan visi dan misi yang ingin dicapai, antara lain:

a. Memperbaiki dan melestarikan lingkungan kawasan Keraton Pakunegara Tayan sebagai kawasan yang "sehat", yaitu sebelum menata kawasan keraton terlebih dahulu memperbaiki landasan agar sehat dan lestari. Perbaikan ini berupa penataan infrastruktur kawasan yaitu kejelasan akses, sirkulasi, utilitas kawasan, tata bangunan dan lingkungan serta penataan di lingkungan tepian air atau sungainya;

b. Langkah berikutnya adalah melakukan proses pemberdayaan masyarakat terhadap pelestarian budaya yang ada di lingkungan tersebut. Melibatkan masyarakat dengan menyediakan fasilitas untuk mendukung kegiatan-kegiatan yang berkaitan dengan pelestarian budaya seperti galeri budaya, balai kuning, rumah tenun dan lainnya. Proses lainnya adalah menata kawasan tepian air sebagai ruang komunal masyarakat. Langkah ini sebagai wujud pelestarian budaya masyarakat di lingkungan keraton dan mendukung kegiatan pariwisata;

c. Langkah terakhir adalah memperkuat dan melestarikan Keraton Pakunegara Tayan dan masjid Jami' sebagai ikon atau citra kawasan. Mendukung proses konservasi Keraton Pakunegara Tayan dan restorasi Masjid Jami' seperti kondisi semula.

Penataan kawasan dilakukan melalui pengembangan kawasan-kawasan tertentu yang layak untuk direvitalisasi baik dari segi setting kawasan sehingga kawasan perkotaan akan lebih terintegrasi dalam satu kesatuan yang utuh dengan sistem kota, terbedayakan ruang ekonominya.

\section{KESIMPULAN}

Dari penelitian ini dapat disimpulkan bahwa Kawasan Keraton Pakunegara Tayan telah mengalami degradasi kualitas ruang, hal ini disebabkan oleh kualitas lingkungan dan masyarakat yang berubah sangat cepat. Perubahan ini harus dapat direspon oleh Kawasan Keraton Pakunegara Tayan supaya dapat meningkatkan kualitas lingkungannya kembali dan mengembalikan Kawasan Keraton Pakunegara Tayan sebagai ikon kota, Cagar budaya dan kawasan waterfront kota Tayan. Untuk meningkatkan kualitas ruang pada kawasan Keraton Pakunegara Tayan diwujudkan dalam citra tiga dimensi merupakan upaya untuk memberikan arahan perwujudan fisik Kawasan Keraton pakunegara Tayan, yang mengacu pada Rencana Tata Ruang (RTR) serta kaidah/ norma-norma sosial kultural setempat, agar tercipta suatu lingkungan yang terencana, tertib, aman, nyaman, serasi, produktif dan berkelanjutan. Ke depannya Arahan Penataan Bangunan dan Lingkungan Kawasan 
Keraton Pakunegara Tayan dapat memberikan arahan lingkungan binaan pada kawasan perencanaan, yang memenuhi kepentingan atau aspirasi masyarakat, pemanfaatan sumber daya dan daya dukung lahan yang optimal, dapat digunakan sebagai bahan masukan untuk penyusunan peraturan-peraturan bangunan pada kawasan perencanaan, serta di masa yang akan datang situs warisan cagar budaya ini dapat tetap terpelihara dan memberikan konstribusi yang positif untuk Kota Tayan pada khususnya dan Kalimantan Barat pada umumnya.

\section{Daftar Pustaka}

Ardhiansyah, N., Widyastuti, D. A. R., \& Septiari, E. D. (2019). Perubahan tata guna lahan kampung Prawirotaman kota Yogyakarta sebagai dampak keberadaan kawasan komersial. ARTEKS : Jurnal Teknik Arsitektur, 3, No. 2, 131-138.

Asirin, \& Zanith, L. (2017). Penataan Lingkungan Sebagai Instrumen Pencegahan Kejahatan Seksual Terhadap Anak Studi Kasus Kota Bandar Lampung. Jurnal Kawistara, 7, No. 1, 67-77.

Drianda, R. P., Kinoshita, I., \& Deviana, F. (2015). Perencanaan Lingkungan Perkotaan yang Aman dari Ancaman Kriminalitas Terhadap Anak: Sebuah Studi Kasus dari Negeri Jepang. Jurnal Perencanaan Wilayah Dan Kota, 26, No. 1, 7-17.

Dwijaya, M. A. (2016). Studi Tata Bangunan dan Lingkungan Di Kelurahan Wameo Kecamatan Batupoaro Kota Baubau. UIN ALAUDDIN MAKASSAR.

Kementrian Pekerjaan Umum. (2007). Peraturan Menteri Pekerjaan Umum Nomor: 06/Prt/M/2007 Tanggal 16 Maret 2007 Tentang Pedoman Umum Rencana Tata Bangunan Dan Lingkungan. Retrieved from http://www.pu.go.id/uploads/services/2011-12-01-12-08-17.pdf

Maulid. (2018). Ini Pinta Raja Tayan kepada Cagub Sutarmidji. Retrieved April 20, 2020, from https://equator.co.id/ website: https://equator.co.id/ini-pinta-raja-tayan-kepada-cagub-sutarmidji/

Moleong, L. J. (2017). Metodologi Penelitian Kualitatif(Edisi Revisi) (6th ed.). Bandung: PT. Remaja Rosda Karya.

Nurfitriati, I. (2015). Rencana Tata Bangunan dan Lingkungan (RTBL) Dalam Menata Ruang kota. Veritas Et Justitia, Vol 1, No, 398-425.

Nurjannah, I. (2017). Kajian Konsep Penataan Kawasan Kota Lama Kendari Berdasarkan Identitas Dan Citra Kotanya. Langkau Betang: Jurnal Arsitektur, 4(2), 144. https://doi.org/10.26418/lantang.v4i2.23253

Presiden Republik Indonesia. (2010). UU RI No 11 tahun 2010 Tentang Cagar Budaya.

Rohe, W. M. (2009). From Local to Global: One Hundred Years of Neighborhood Planning. Journal of The American Planning Association, 75, No. 2, 209-230.

Sarjiyanto, \& Inagurasi, L. H. (2015). Perdagangan di Pertemuan Sungai Kapuas dan Tayan, Sanggau, Kalimantan Barat, Abad Ke 19. PURBAWIDYA: Jurnal Penelitian Dan Pengembangan Arkeologi, Vol. 7(1), pp $71-88$.

Shirvani, H. (1985). The Urban Design Process. New York: Van Nostrand Reinhold Company.

Tallo, A.J., \& Paramita, D. . (2015). Identifikasi Tingkat Partisipasi Masyarakat Studi Kasus Kampung Lorotan, Kelurahan Kotalama, Kota Malang. Jurnal Kawistara, 5, No. 3, 275-286.

Yahya, M. (2015). Kajian Tata Bangunan dan Lingkungan pada Koridor Jalan Perintis Kemerdekaan Kota Makassar. Prosiding Temu Ilmiah IPLBI 2015, B033-B038.

Yunianto, A. D., S.R.P. Sitorus, \& Munibah, K. (2016). Analisis dan Arahan Pengembangan Ruang Terbuka Hijau Dalam Mendukung Green City Kota Ungaran Kabupaten Semarang. Jurnal Kawistara, 6, 1-9. 